\title{
Variation with Land Use of Immune Function and Prevalence of Avian Pox in Galapagos Finches
}

\author{
MAXINE ZYLBERBERG,${ }^{*} \dagger \ddagger$ KELLY A. LEE, ${ }^{*}$ KIRK C. KLASING,${ }^{*}$ AND MARTIN WIKELSKIऽ \\ *University of California, Davis, One Shields Avenue, Davis, CA 95616, U.S.A. \\ \Max Planck Institute of Ornithology, Eberhard-Gwinner-Str. 82319, Seewiesen, Germany \\ †Current address: California Academy of Sciences, 55 Music Concourse Drive, San Francisco, CA 94118, U.S.A.
}

\begin{abstract}
Introduced disease has been implicated in recent wildlife extinctions and population declines worldwide. Both anthropogenic-induced change and natural environmental features can affect pathogen spread. Furthermore, environmental disturbance can result in changes in stress physiology, nutrition, and social structure, which in turn can suppress immune system function. However, it remains unknown whether landscape variation results in beterogeneity in host resistance to pathogens. Avian pox virus, a pathogen implicated in avian declines and extinctions in Hawaii, was introduced to the Galapagos in the 1890s, and prevalence (total number of current infections) has increased recently in finches. We tested whether prevalence and recovery trends in 7 species of Galapagos finches varied by elevation or human land use. To do so, we used infection data obtained from 545 wild-caught birds. In addition, we determined whether annual changes in 4 aspects of innate immune function (complement protein activity, natural antibody activity, concentration of PIT54 protein, and heterophil:lymphocyte ratio) varied by elevation or land use. Prevalence and recovery rates did not vary by elevation from 2008 to 2009. Avian pox prevalence and proportion of recovered individuals in undeveloped and urban areas did not change from 2008 to 2009. In agricultural areas, avian pox prevalence increased 8-fold (from 2\% to 17\% of 234 individuals sampled) and proportion of recovered individuals increased (11\% to 19\%) from 2008 to 2009. These results suggest high disease-related mortality. Variation in immune function across human land-use types correlated with variation in both increased prevalence and susceptibility, which indicates changes in innate immune function may underlie changes in disease susceptibility. Our results suggest anthropogenic disturbance, in particular agricultural practices, may underlie immunological changes in host species that themselves contribute to pathogen emergence.
\end{abstract}

Keywords: Camarhynchus, Certhidea, ecoimmunology, Geospiza, innate immune function, introduced pathogen, passerine

Variación con el Uso de Suelo de la Función Inmune y la Prevalencia de la Varicela Aviar en Pinzones de las Galápagos

Resumen: Las enfermedades introducidas han sido implicadas en extinciones y declinaciones poblacionales recientes en todo el mundo. Tanto el cambio inducido antropogénicamente como los atributos ambientales naturales pueden afectar la dispersión de la enfermedad. Más aun, la perturbación ambiental puede resultar en cambios en la fisiología del estrés, la nutrición y estructura social, que a su vez puede suprimir el funcionamiento del sistema inmune. Sin embargo, no se conoce si la variación del paisaje resulta en beterogeneidad de la resistencia del buésped a patógenos. El virus de la varicela aviar, un patógeno implicado en declinaciones y extinciones de aves en Hawái, fue introducido a las Galápagos en la década de 1890, y la prevalencia (número total de infecciones actuales) ha incrementado en los pinzones recientemente. Probamos si la prevalencia y las tendencias de recuperación en 7 especies de pinzones de las Galápagos variaron con la elevación y el uso de suelo por humanos. Para ello, usamos datos de infección obtenidos de 545 aves silvestres capturadas. Adicionalmente, determinamos si los cambios anuales en 4 aspectos de la función inmune innata (actividad de la proteína complementaria, actividad de anticuerpo natural, concentración

$\ddagger$ Address for correspondence: California Academy of Sciences, 55 Music Concourse Drive, San Francisco, CA 94118, U.S.A., email mzylberberg@ucdavis.edu 
de la proteína PIT54, y la relación heterofilo:linfocito) variaron con la elevación o el uso de suelo. La prevalencia y las tasas de recuperación no variaron con la elevación de 2008 a 2009. La prevalencia de viruela aviar y la proporción de individuos recuperados en áreas no desarrolladas y urbanas no cambió de 2008 a 2009. En áreas agrícolas, la prevalencia de viruela aviar incrementó 8 veces (de 2\% a $17 \%$ de 234 individuos muestreados) y la proporción de individuos recuperados incrementó (11\% a 19\%) de 2008 a 2009. Estos resultados sugieren una alta mortalidad relacionada con la enfermedad. La variación en la función inmune en los diferentes tipos de uso de suelo por humanos se correlacionó con la variación del incremento de prevalencia y susceptibilidad, lo cual indica que cambios en la función inmune innata pueden subyacer en cambios en la susceptibilidad a la enfermedad. Nuestros resultados sugieren que la perturbación antropogénica, particularmente las prácticas agrícolas, puede comprender cambios inmunológicos en las especies huésped que a su vez contribuyen surgimiento de patógenos.

Palabras Clave: Camarhynchus, Certhidea, ecoinmunología, función inmune innata, Geospiza, paseriforme, patógeno introducido

\section{Introduction}

Introduced diseases have been implicated as a decisive factor in recent wildlife extinctions and population declines (Diamond 1994; Wikelski et al. 2004), and variation in habitat use often plays a key role in determining wildlife exposure to pathogens (e.g., Nunn \& Heymann 2005). Furthermore, anthropogenic ecosystem change, such as conversion of undisturbed areas to agriculture, can change the ecology, distribution, and effect of parasites or pathogens within their host species and can lead to disease emergence (i.e., an increase in prevalence of a disease) (Patz et al. 2000; Chasar et al. 2009). For example, anthropogenic changes can increase vector abundance by providing resources necessary for vector survival (i.e., fresh water; Whiteman et al. 2005), which in turn can affect pathogen spread through host populations. Mosquitoes are a ubiquitous class of vector and have played a decisive role in the introduction, establishment, and spread of pathogens such as avian pox virus (APV) in island ecosystems (van Riper et al. 2002). In addition to anthropogenic-induced changes, natural features, such as elevation gradients, can affect the spread of introduced pathogens. For example, the prevalence (total number of current infections in a population) of introduced APV in Hawaii is highest in midelevation areas, where there is the most overlap between native birds and introduced mosquitoes (van Riper et al. 2002). Similarly, in the Galapagos, wet highland areas are thought to provide more favorable conditions for at least one introduced parasite, the fly Philornis downsi (O'Connor et al. 2010). However, it remains unknown whether landscape variation results in differences in host resistance to pathogens through variation in immune-system function. The Galapagos islands, and the Galapagos finches, in particular, are ideal for examining anthropogenic and elevation effects on the spread of avian pathogens and the relation between disease and interannual variation in immune function for several reasons. First, the habitat of Galapagos finches spans relatively undisturbed areas to areas that have been heavily affected by human use. Although only
3.3\% of Galapagos lands are developed, multiple islands have extensive urban (populations over 30,000 people) and agricultural areas (Wiedenfeld \& Jiménez-Uzcátegui 2008). The importance of anthropogenic change is highlighted by the recent introduction of 2 potential mosquito vectors of APV, Aedes aegypti and Culex quinquefasciatus. These mosquitoes currently are localized in developed areas (Whiteman et al. 2005; Bataille et al. 2009).

Second, Galapagos finches are host to APV, a pathogen that causes the avian pox disease (AP), which is characterized by distinctive cutaneous lesions. Avian pox has been implicated as a major factor in avian declines and extinctions in Hawaii (van Riper et al. 2002). APV was introduced to the Galapagos in the 1890s (Parker et al. 2011). It spread through the Galapagos avifauna and, along with other introduced pathogens, is thought to be driving population declines and range contractions (Wikelski et al. 2004). Furthermore, the proportion of Galapagos finches affected by AP increased from 2000 to 2009 (Kleindorfer \& Dudaniec 2006; Zylberberg et al. 2012). However, evidence suggests that APV infection and recovery rates are not homogeneous across finch populations and that they vary by elevation and species (Kleindorfer \& Dudaniec 2006; Zylberberg et al. 2012).

Third, immune function varies among conspecific Galapagos finch populations (Lindström et al. 2004). This phenotypic heterogeneity among groups provides the potential for geographic variation in immune function and an ideal opportunity to examine how immune function varies with different landscape features. Just as variation in exposure to vectors may help determine the level of pathogen exposure for distinct social groups, populations, or species, the strength of innate (nonspecific) immunity at an individual or group level will help determine whether and how a novel pathogen spreads through a population.

We examined APV prevalence in 7 species of finch on Santa Cruz Island from 2008 to 2009: Small Ground Finch (Geospiza fuliginosa), Medium Ground Finch (Geospiza fortis), Large Ground Finch (Geospiza magnirostris), Common Cactus Finch (Geospiza scandens), Small Tree 
Finch (Camarbynchus parvulus), Woodpecker Finch (Camarbynchus pallida), and Warbler Finch (Certbidea olivacea). We tested 2 hypotheses regarding geographic variation and temporal patterns in disease prevalence (proportion of actively infected individuals at a point in time). Specifically, we tested whether AP prevalence and recovery trends varied by elevation (as suggested by Kleindorfer and Dudaniec [2006]) or according to human land-use patterns. We also tested the hypothesis that species-specific factors (e.g., nutrition, exposure to stressors, or exposure to other pathogens) result in variation in body condition, which in turn alters susceptibility to APV. This hypothesis predicts body condition will vary indirectly with prevalence. An alternate hypothesis is that variation in immune function underlies observed geographic variation in changes in AP prevalence and recovery rates. It is the constitutive immune function of healthy (not yet infected) individuals in a particular group that determines susceptibility to infection on exposure and initial success in coping with infection. Therefore, this hypothesis predicts a decrease in innate immune function of healthy individuals only in those species that show an increase in AP prevalence over time. It is possible, but not necessary, that body condition and immune function are linked; therefore, for simplicity, we considered them separately.

\section{Methods}

\section{Study Site}

Santa Cruz Island, Galapagos, Ecuador, is approximately $1000 \mathrm{~km}$ from the Ecuadorian mainland $\left(00^{\circ} 38^{\prime} \mathrm{S}\right.$ $\left.90^{\circ} 22^{\prime} \mathrm{W}\right)$. To examine the effect of land-use patterns and elevation on AP prevalence, we sampled birds at 6 sites (Fig. 1) in 3 different land-use types (urban, agricultural, and undeveloped sites) and 2 elevation categories (lowland, 0-200 m; highland, 300-500 m) as defined by Kleindorfer and Dudaniec (2006) (Table 1). We selected

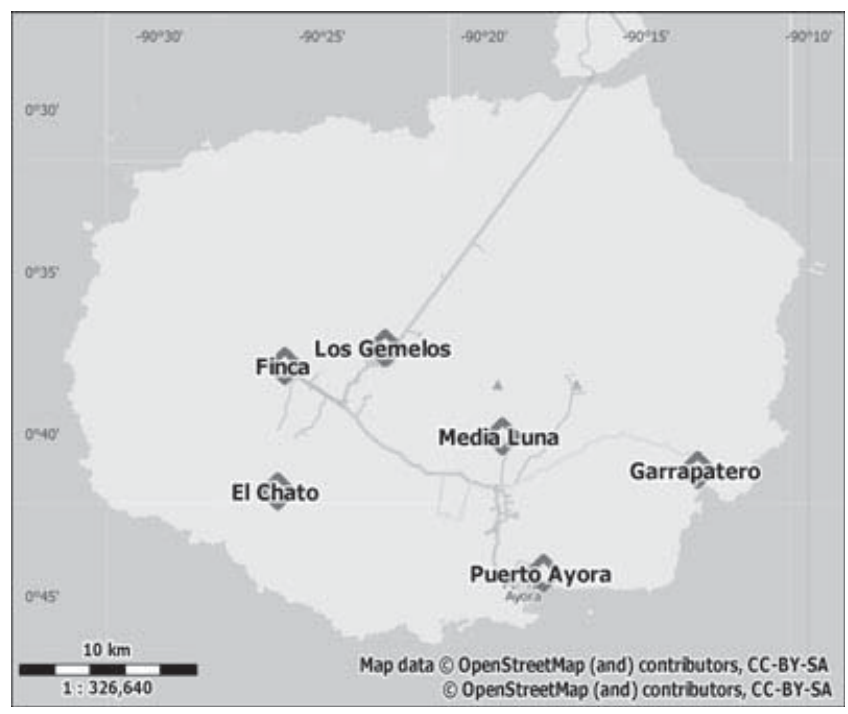

Figure 1. Location of the 6 study sites on Santa Cruz Island, Galapagos: Puerto Ayora, lowland urban; Los Gemelos, highland undeveloped; Garrapatero, lowland undeveloped; El Chato, lowland agricultural; Finca, highland agricultural; Media Luna, bighland agricultural (lowland, O-200 m elevation; bighland, 300-500 m elevation; lines, roads; triangles, elevation peaks).

the study sites to represent the range of vegetation types and precipitation present in each land-use and elevation category. The single urban site was in Puerto Ayora (population $>30,000$ ) in the lowland arid zone. Because there was only one urban area on Santa Cruz Island, we could not sample birds from a second urban site. Three sites were in the agricultural zone of the island, which contained a combination of small farms, fruit plantations, and cattle ranches. One agricultural site was in the lowlands and 2 were in the highlands. Two sites were in undeveloped areas ( 1 arid lowland and 1 wet highland). The Galapagos is well known for extreme fluctuations in

Table 1. Number of individuals of each Galapagos finch species sampled by location and year. ${ }^{a}$

\begin{tabular}{|c|c|c|c|c|c|c|}
\hline \multicolumn{7}{|c|}{ Location } \\
\hline & \multirow{2}{*}{$\frac{\text { urban }}{\text { low }}$} & \multicolumn{3}{|c|}{ agricultural } & \multicolumn{2}{|c|}{ undeveloped } \\
\hline & & $\begin{array}{c}\text { low } \\
\text { El Chato }\end{array}$ & $\begin{array}{c}\text { bigh } 1 \\
\text { La Finca }\end{array}$ & $\begin{array}{c}\text { bigh } 2 \\
\text { Media Luna }\end{array}$ & $\begin{array}{c}\text { low } \\
\text { Garrapatero }\end{array}$ & $\begin{array}{c}\text { bigh } \\
\text { Los Gemelos }\end{array}$ \\
\hline Small ground finch & 28,25 & 16,31 & 9,43 & 16,18 & 12,30 & 9,22 \\
\hline Large ground finch & 1,2 & 1,0 & 5,0 & 0,0 & 2,0 & 0,1 \\
\hline Cactus finch & 6,8 & 0,0 & 0,0 & 0,0 & 1,7 & 0,0 \\
\hline Small tree finch & 0,0 & 16,2 & 8,16 & 0,0 & 0,6 & 21,21 \\
\hline Warbler finch & 0,0 & 0,0 & 0,0 & 9,0 & 0,0 & 2,0 \\
\hline Woodpecker finch & 0,0 & 0,0 & 0,0 & 0,0 & 0,0 & 2,0 \\
\hline Total & 76,61 & 38,37 & 41,74 & 25,19 & 21,66 & 35,52 \\
\hline
\end{tabular}

${ }^{a}$ First number, 2008; second number, 2009; low, lowland; high, highland. 
(a)

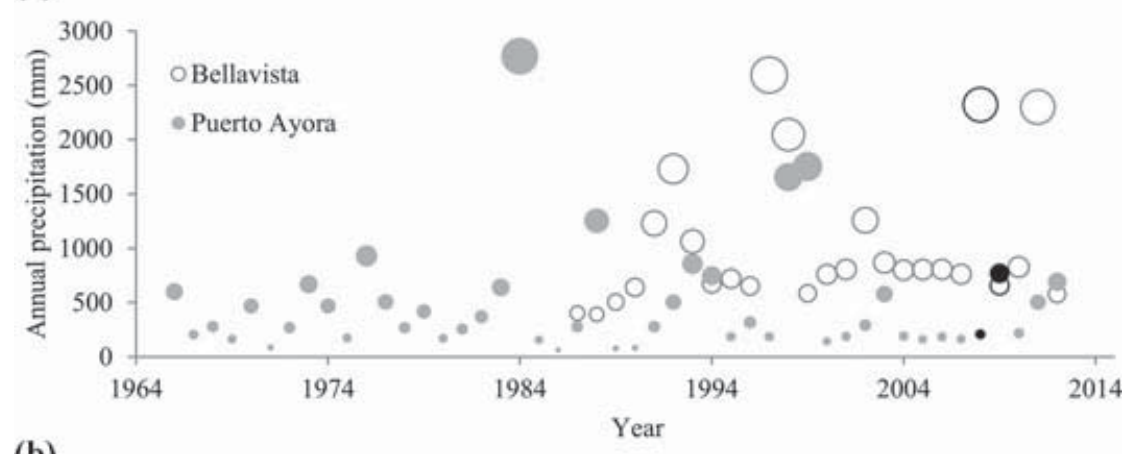

Figure 2. Precipitation on Santa Cruz Island, Galapagos: (a) total annual precipitation in Puerto Ayora in 1965-2012 and Bellavista in 1987-2012 (circle size increases proportional to the amount of precipitation; black circles, study years) and (b) total daily (b) precipitation from approximately 3 months prior to sampling until 1 week prior to the end of sampling (reflects period during which infected individuals may have become infected) during 2008 (gray lines) and 2009 (black lines) in the city of Puerto Ayora in the arid lowlands (dashed lines) and the village of Bellavista in the wet highlands (solid lines).

precipitation as a result of the El Niño weather pattern. However, 2008 and 2009 were neither particularly wet nor particularly dry years on average (Fig. 2a). There was little variation in precipitation between 2008 and 2009 from 3 months prior to the start of sampling through 1 week prior to the end of sampling (Fig. 2b), the time during which individuals infected with APV when sampled would likely have become infected (van Riper \& Forrester 2007).

\section{Trapping and Sample Collection}

To obtain immune function, body condition, and AP prevalence data, we caught birds in mist nets during the breeding season (January-February) in 2008 and 2009. For each captured bird, we measured mass and tarsus length, attached a leg band, and collected blood samples in heparinized microcapillary tubes within $30 \mathrm{~min}$ of capture. We used one drop of each blood sample to make a blood smear, preserved another drop on filter paper (Whatman) infused with 0.5M EDTA, and kept the remainder of each sample on ice until we could centrifuge it. After centrifugation, we collected and froze the plasma. We kept samples on ice for 4-6 h before centrifugation. We air dried blood smears, fixed them for $1 \mathrm{~min}$ with $100 \%$ methanol and later stained them with the Hema 3 staining system (Fisher Scientific, Pittsburgh, PA, U.S.A.). We used the ratio of mass to tarsus length cubed as a measure of body condition (Freeman \& Jackson 1990).

We examined each individual for evidence of current or past infection with APV (Lindström et al. 2004). Work- ers who scored lesions received instruction on identification of active and healed pox lesions from Gustavo Jiménez-Uzcátegui, DVM, Charles Darwin Research Station, Galapagos. We classified individuals with active, swollen lesions as currently infected with APV (hereafter infected) and birds with lesion-induced scarring and missing digits as recovered (hereafter recovered). Although confirmation of APV as the cause of cutaneous lesions can be done via histology, we considered this step unnecessary due to the well-documented presence of APV in the Galapagos and lack of other pathogens resulting in similar symptoms (Duffy \& Harcourt 1981; Lindström et al. 2004). We processed all birds with the approval of University of California, Davis Institutional Animal Care, and Use Committee protocol 13171.

\section{Immune Function}

We measured 4 aspects of innate immune function in our study species: (1) complement activity (defined later), (2) natural antibody activity, (3) concentration of PIT54 acute phase protein, and (4) heterophil:lymphocyte ratio. Each of these aspects of the innate immune system plays an integral and complementary role in the first line of defense against novel pathogens. Complement is a system of proteins that activates the lysis of foreign cells, alters the molecular structure of viruses, enhances antibodymediated viral neutralization, and destroys viruses directly through virolysis (Hirsch 1982; Janeway et al. 2001). Natural antibodies are immunoglobins that bind novel pathogens, such as bacteria and viruses, facilitate hagocytosis, and initiate the complement cascade 
resulting in cell lysis (Casali \& Schettino 1996; Caroll \& Prodeus 1998). The PIT54 protein performs a similar function in birds as haptoglobin in mammals (i.e., minimizes damage to the host during inflammation associated with viral, bacterial, and parasitic infections, and stimulates white blood cell response on exposure to a pathogen) (Wicher \& Fries 2006; Quaye 2008). Lymphocytes play an important role in the acquired antibody and cell-mediated immune responses, and heterophils are phagocytic cells that engulf and digest pathogens. The heterophil:lymphocyte ratio is used as a measure of the acute phase response to an infectious challenge and a measure of stress and general health (Gross \& Siegel 1983). Together, these measures afford a broad view of the innate immune system by providing information on both inducible and constitutive components of innate immunity.

Although immune parameters change with infection status, when recorded in healthy individuals these measures provide information on investment in both innate and adaptive immunity (as described earlier). Therefore, to simplify interpretation of our results, we limited our analyses of immune parameters to individuals with no signs of AP, infection with another pathogen, or other illnesses (hereafter healthy individuals). For example, we excluded individuals with abnormal crusts, growths, or excessive lethargy and those with any sign of AP.

\section{Hemolysis-Hemagglutination and PIT54 Assays}

We carried out the hemolysis-hemagglutination assay, which measures levels of complement activity and natural antibody activity, as described in Matson et al. (2005). We modified the original protocol and used $10 \mu \mathrm{L}$ of plasma, rather than $25 \mu \mathrm{L}$ because our sample size was small; we scaled the quantity of all reagents accordingly.

The PIT54 protein present in avian plasma can be measured with the same commercially available kit used to measure mammalian haptoglobin. This kit has been used successfully with a variety of songbirds, including sparrows and finches (Matson 2006; Millet et al. 2007). As in Millet et al. (2007), we used a commercial kit (Tridelta Diagnostics, Morris Plains, NJ, U.S.A.) to determine the concentration of this acute phase protein in plasma samples. We modified the protocol and used $5 \mu \mathrm{L}$ of plasma rather than the $10 \mu \mathrm{L}$ that the kit protocol suggests and also halved the amount of each reagent added to samples. We diluted the kit-provided standard and ran it in duplicate on each plate. We used the average of the 2 standard curves to calculate the concentrations of PIT54 in experimental samples on the basis of the amount of color change they exhibited. We ran adult chicken plasma in triplicate on each plate as a positive control. We read plates at an absorbance of $650 \mathrm{~nm} 5$ min after the second reagent was added.

\section{Heterophil:Lymphocyte Ratio}

To evaluate the heterophil:lymphocyte ratio, we examined smears under an oil immersion lens $(1000 \times$ magnification). For each smear, we examined 10,000 erythrocytes and counted and identified the white blood cells occurring within the area of these erythrocytes on the basis of morphological characteristics as described in Avian Hematology and Cytology (Campbell 1995). The microscope fields we examined were evenly distributed over the entire surface of the smear to avoid oversampling a single area.

\section{Statistical Analyses}

To determine whether the change in proportion of infected and recovered individuals varied by elevation or land-use type (covered above), we constructed 4 logisticregression models that examined (1) change in infection rates by elevation, (2) change in recovery rates by elevation, (3) change in infection rates by land-use type, and (4) change in recovery rates by land-use type. The first and third models had infection rate as the dependent variable, whereas the second and fourth had recovery rate as the dependent variable. The independent variables for the first and second model were year, elevation, and the interaction between year and elevation. The independent variables for the third and fourth model were year, land-use type, and the interaction between year and land-use type. Categorical variable coefficients are often calculated using an arbitrary base. However, for the purposes of this analysis the grand mean of all landuse effects was used as the base value, which allowed us to estimate all measured land-use effects with a post hoc calculation method. This calculation allowed us to interpret the estimates directly, rather than having to compare them with a base value. To avoid bias resulting from nonindependence of samples within study sites, we also ran mixed-effects logistic-regression models with either elevation or land use as random effects grouping factors and compared these models with the Akaike information criterion. The results of this analysis were comparable to those with logistic-regression models, so we present the logistic model output because it is easier to evaluate and interpret $R^{2}$ than the Akaike information criterion. When there was a categorical difference (specifically, by land-use type) in change in proportion of infected and recovered individuals over time, we tested for differences in body condition and immune function. We used 2-tailed $t$ tests to test for differences in body condition (mass/tarsus ${ }^{3}$ ) within each land-use type between 2008 and 2009. Before testing for differences in immune function by land-use type, we used 2-way analysis of variance to test for differences in immune function among species and among breeding-condition males (presence of an enlarged cloacal protuberance), breeding-condition females 
Table 2. Results of logistic-regression model of variation in avian pox infection rates in Galapagos finches by year (2008, 2009) and land-use type on Santa Cruz Island, Galapagos.

\begin{tabular}{|c|c|c|c|c|}
\hline Term & Estimate & $S E$ & $\chi^{2}$ & $p$ \\
\hline Intercept & -3.610 & 0.414 & 76.2 & $<0.0001$ \\
\hline Year & 0.797 & 0.554 & 2.06 & 0.15 \\
\hline Land use (agricultural) $^{a}$ & -0.319 & 0.584 & 0.30 & 0.59 \\
\hline Land use (undeveloped) & 0.317 & 0.587 & 0.29 & 0.59 \\
\hline Land use (urban) & 0.002 & 0.585 & 0.00 & 0.10 \\
\hline Land use (agricultural) × year (2008 to 2009) & 1.540 & 0.704 & 4.81 & 0.03 \\
\hline Land use (undeveloped) $\times$ year $(2008$ to 2009$)$ & -0.264 & 0.728 & 0.13 & 0.72 \\
\hline Land use (urban) $\times$ year $(2008$ to 2009$)$ & -1.280 & 0.904 & 2.00 & 0.16 \\
\hline
\end{tabular}

${ }^{a}$ The overall model was significant and explained $10 \%$ of variation in infection rates $\left(n=545, d f=5, p<0.0001, R^{2}=0.106\right)$.

(presence of a brood patch), and nonbreeding adults. Because our study was conducted at the beginning of the breeding season, no juveniles were present in the sample population, but nonbreeding adults are likely to account for a higher proportion of yearlings than breeding adults. We found no differences in immune function among species or among breeding-condition males, breedingcondition females, and nonbreeding adults, so we lumped all individuals for analyses of immune function by landuse type. We used 2-way ANOVA to test whether immune function varied between 2008 and 2009 by land-use type. Statistical tests for differences in body condition and immune function included only healthy individuals (defined earlier). All statistical analyses were conducted using JMP 7.0.1.

\section{Results}

We sampled 545 individuals for pox infection status (Table 1). Of these, we obtained and analyzed blood samples from 403 individuals (185 Small Ground Finches, 118 Medium Ground Finches, 84 Small Tree Finches, 16 Cactus Finches). When the blood sample was not large enough to run each immune test, we randomly assigned samples to a test type. Smears were examined for a random subset of individuals.

The model of change in infection rates by elevation from 2008 to 2009 was significant, but had low explanatory power $\left(n=545\right.$, df $=3, p=0.0045, R^{2}=$ 0.049). Within this model, year had a significant effect $(p=0.0021)$; prevalence increased over time. Neither elevation nor the interaction of elevation and year were significant. This result indicates the increase in prevalence did not vary between highland and lowland sites. The model of change in recovery rates by elevation was neither significant $\left(n=545\right.$, df $=3, p=0.65, R^{2}=$ $0.0037)$, nor were any of the input terms significant. Thus, recovery rate did not change overtime overall or within highland or lowland sites. Over time infection rates increased from $2.2 \%$ to $8.5 \%$ in the lowlands and from $2.9 \%$ to $11 \%$ in the highlands, and proportion of recovered individuals increased from $14.8 \%$ to $16.5 \%$ in the lowlands and $10.9 \%$ to $14.5 \%$ in the highlands.

The model of change in infection rates by land-use type was significant and explained just over 10\% of observed variation ( $n=545$, df $=5, p<0.0001, R^{2}=0.106$ ) (Table 2). In this model, the interaction term between year and agricultural areas was significant $(p=0.02)$, and prevalence increased in agricultural areas from 2008 to 2009. No other terms were significant, which indicates prevalence did not increase significantly overall from 2008 to 2009 and did not increase in urban or undeveloped areas.

The model of change in recovery rates by land-use type was neither significant $(n=545$, df $=5, p=0.49$, $R^{2}=0.0097$ ), nor were any of the input terms significant. Thus, recovery rate did not change over time overall or within agricultural, undeveloped, or urban areas. When we examined change in AP prevalence by land-use type, we found there was no difference between 2008 and 2009 in undeveloped or urban areas $\left(\chi^{2}=0.46, n=174\right.$, $\mathrm{df}=172, p=0.49$ and $\chi^{2}=0.16, n=137, \mathrm{df}=135$, $p=0.69$, respectively) (Fig. 3). In contrast, AP prevalence in agricultural areas increased significantly from $1.9 \%$ in 2008 to $16.9 \%$ in 2009 ( $\chi^{2}=16.78, n=234, \mathrm{df}=232, p<$ 0.0001 [covered in Methods]). There was also no change in the proportion of recovered birds in undeveloped and urban areas from 2008 to 2009, whereas in agricultural areas there was a significant increase in the proportion of recovered birds from $10.6 \%$ in 2008 to $18.5 \%$ in 2009 $\left(\chi^{2}=2.9, n=234, \mathrm{df}=232, p=0.089\right)$.

There was no difference in immune function by species (PIT54: $n=288, \mathrm{df}=287, p=0.56$; natural antibodies: $n=362$, df $=361, p=0.74$; complement: $n=329$, $\mathrm{df}=328, p=0.34 ; \mathrm{H}: \mathrm{L}: n=242, \mathrm{df}=241, p=0.64$ ). Nor was there a difference, after Holm-Bonferroni adjustment for multiple comparisons, in immune function between breeding-condition males, breeding-condition females, and nonbreeding adults (PIT54: $n=288$, df $=$ 287, $p=0.31$; natural antibodies: $n=362$, df $=361, p=$ 0.45; complement: $n=329$, df $=328, p=0.92$; H:L: $n=$ 242 , df $=241, p=0.038)$. Therefore, to examine differences in immune function by land-use type, we lumped all healthy finches sampled. 


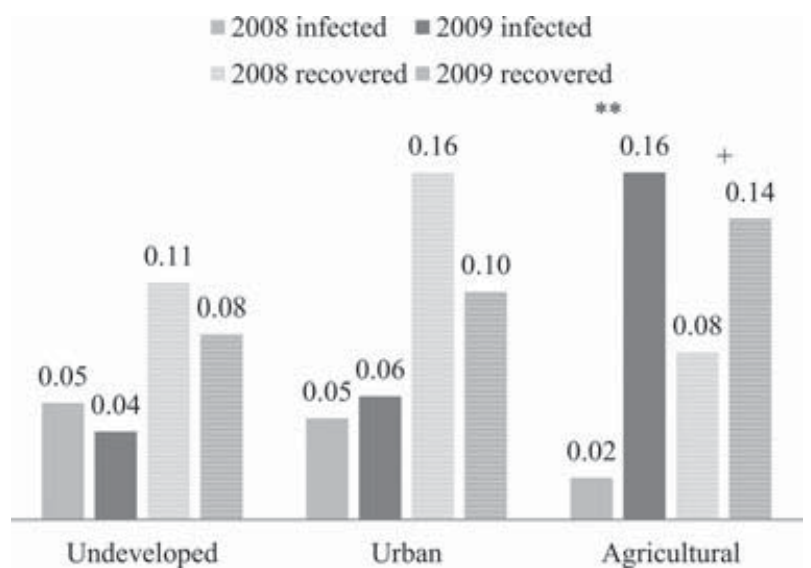

Figure 3. Proportion of all Galapagos finches sampled in each land-use type (urban, agricultural, and undeveloped) infected with or recovered from avian pox in 2008 and 2009 (proportions above bars; +, $p<0.1 ;^{* *}, p<0.0001$ ) and significant differences in proportion of infected individuals or recovered individuals from 2008 to 2009 (likelibood-ratio chi-square tests).

The PIT54 levels among healthy finches in agricultural areas decreased significantly from 2008 to 2009 (Table 3). This decrease was accompanied by an increase in natural antibody levels, but this change was not significant after Holm-Bonferroni correction for multiple tests. In the same period, PIT54 levels decreased significantly and natural antibody levels increased significantly among healthy finches in undeveloped areas. There was no change in any immune parameter in urban areas. There was no change in body condition in any land-use type from 2008 to 2009.

\section{Discussion}

Although APV is considered self-limiting in mainland avian populations, it is a disease of concern in remote island systems (van Riper et al. 2002; van Riper \& Forrester 2007). For example, APV is associated with population declines and species extinctions in Hawaii and decreased recruitment of juvenile mockingbirds into the adult population in the Galapagos (Vargas 1987; van Riper et al. 2002; Atkinson et al. 2005). APV was first observed in the Canary Islands in 2000 and has since spread to infect $50 \%$ of Short-toed Larks (Calandrella rufescens) (Smits et al. 2005). However, relatively little is known about the threat AP poses to endemic island species outside of Hawaii.

Our results suggest APV may pose the highest risk to the Galapagos avifauna in agricultural systems. We observed a change in AP prevalence and proportion of recovered individuals in agricultural, but not undeveloped or urban, areas from 2008 to 2009. In agricultural areas, there was a more than 8 -fold increase in AP prevalence (from $2 \%$ to $17 \%$ ) that was accompanied by a much smaller increase in the proportion of recovered individuals. This indicates the rate of survival following APV infection in agricultural areas is low. The lack of change in the heterophil:lymphocyte ratio suggests there has not been a change in the overall health of individuals in agricultural areas from 2008 to 2009. Instead, reduced survival in agricultural areas may be due to a decrease in protective immunity, as indicated by the observed decrease in PIT54 levels in agricultural areas. Possible causes underlying changes in immune function could include exposure to endocrine disruptors or immunosuppressive pesticides and herbicides, consumption of highly available but nutritionally incomplete domestic seeds, or stress from the

Table 3. Results of a 2-way analysis of variance testing for a change in measures of innate immune function of healthy Galapagos finches (no sign of avian pox infection or other disease) by land-use type from 2008 to 2009 on Santa Cruz Island, Galapagos.

\begin{tabular}{|c|c|c|c|c|c|c|c|}
\hline $\begin{array}{l}\text { Immune } \\
\text { parameter }\end{array}$ & Land-use type & F ratio & $n$ & $d f$ & $p$ & $\begin{array}{l}\text { Immune } \\
\text { change }^{a}\end{array}$ & $\begin{array}{c}\text { Prevalence } \\
\text { change }^{b}\end{array}$ \\
\hline \multirow[t]{3}{*}{$\operatorname{PIT} 54^{c}$} & agricultural & 22.05 & 115 & 113 & $<0.0001^{d}$ & $\downarrow$ & $\uparrow$ \\
\hline & undeveloped & 8.61 & 95 & 93 & $0.0042^{*}$ & $\downarrow$ & - \\
\hline & urban & 0.99 & $4-3$ & 41 & 0.32 & - & - \\
\hline Natural & agricultural & 4.98 & 123 & 121 & 0.028 & $\uparrow$ & $\uparrow$ \\
\hline antibodies & undeveloped & 17.54 & 99 & 97 & $<0.0001^{*}$ & $\uparrow$ & - \\
\hline \multirow[t]{3}{*}{ Complement } & agricultural & 1.33 & 128 & 126 & 0.25 & - & $\uparrow$ \\
\hline & undeveloped & 1.79 & 100 & 98 & 0.19 & - & - \\
\hline & urban & 0.055 & 65 & 63 & 0.82 & - & - \\
\hline Heterophil: & agricultural & 2.12 & 68 & 66 & 0.15 & - & $\uparrow$ \\
\hline \multirow[t]{2}{*}{ lymphocyte } & undeveloped & 1.84 & 54 & 52 & 0.18 & - & - \\
\hline & urban & 0.019 & 38 & 36 & 0.89 & - & - \\
\hline
\end{tabular}

${ }^{a}$ Arrows indicate directionality of statistically significant change in immune function of healthy individuals from 2008 to 2009 ( $p<0.05$ ).

${ }^{b}$ Arrows indicate the directionality of statistically significant change in prevalence from 2008 to $2009(p<0.05)$.

${ }^{c}$ The PIT5 4 acute phase protein; complement system of immune proteins.

${ }^{d}$ Values with an asterisk remain significant at the $p=0.05$ level after Holm-Bonferroni correction for multiple comparisons. 
presence of domestic animals and human activities (stressors whose effects on wildlife vary between urban and agricultural areas) (Thomas \& House 1989; Fairbrother et al. 2004; Quinn \& Ottinger 2006; Fokidis et al. 2009). In any case, the rapid increase in prevalence in agricultural areas is a cause for concern. Although a change in immune function appeared to contribute to the change in AP prevalence seen in agricultural areas, it is likely only one factor underlying variation in AP prevalence.

It is possible that a difference in the risk of exposure to APV among individuals in the different land-use types contributed to observed variation in AP prevalence. Introduced $A$. aegypti and C. quinquefasciatus, potential APV vectors, are associated with human settlement (Whiteman et al. 2005; Bataille et al. 2009). This suggests that vector-borne transmission of APV could occur at higher rates in urban and agricultural areas than in undeveloped areas. Furthermore, the dramatic fluctuations in precipitation in the Galapagos could increase introduced vector populations in particularly wet years and thereby increase APV transmission. Although this variation in precipitation may be important to long-term APV dynamics, it is unlikely to be a factor in the observed increase of AP in agricultural areas from 2008 to 2009 because these years had similar precipitation in the days and months prior to sampling (Fig. 2b).

In addition to being vector-borne, APV can be transmitted directly through contact between individuals. Urban and agricultural areas in the Galapagos have unnaturally concentrated food and freshwater resources that, anecdotally, appear to be associated with higher finch densities and larger feeding flocks. Indeed, provisioning by humans tends to increase bird abundance (Fuller et al. 2008). Furthermore, APV is a density-dependent pathogen that spreads more rapidly as host and vector abundance increase (van Riper et al. 2002). Thus, behavioral factors may underlie variation in exposure risk by land-use type because density and social-network size can play a critical role in the direct transmission of pathogens (e.g., Hosseini et al. 2004; Meyers et al. 2004). We suggest future studies examine variation in pox prevalence in the nonbreeding as well as breeding season because host physiology (i.e., body condition and hormones) and vector abundance (as a result of climactic variation) vary between seasons and in combination may result in seasonal variation in disease dynamics that will in turn affect interannual disease dynamics. A long-term data set that includes data on vector abundance, host physiology, density, social structure, and a range of environmental characteristics will be critical in developing a thorough understanding of the interannual dynamics of this pathogen in the Galapagos avifauna.

Few researchers have investigated whether anthropogenic disturbance affects immune function, although environmental disturbance is known to result in changes in stress physiology, nutrition, density, and social struc- ture, which in turn can suppress immune system function (Kidd 2004; Suorsa et al. 2004; Hawley et al. 2006; Matson et al. 2006). The difference we found in change in immune function between land-use types suggests that individuals in these different areas may be experiencing different ecological pressures and adjusting their investment in physiological processes and life-history strategies accordingly. Thus, just as anthropogenic disturbance and changes in land-use can change host-pathogen dynamics, human disturbance could underlie immunological changes in host species that contribute to pathogen emergence (i.e., increases in disease prevalence).

In comparing AP prevalence and immune function between land-use types, it is worth noting that on Santa Cruz Island, as elsewhere, land-use type is linked to other environmental characteristics such as temperature, precipitation, and vegetation. Urban and agricultural areas are in arid and wet areas, respectively, whereas undeveloped areas occur in both climate types. Thus, it is possible that the patterns we observed did not result from landuse type per se, but that land-use type simply coincided with some other ecologically important attribute of the agricultural zone. However, investigators conducting a study of vectors of avian pathogens in Hawaii suggest that transmission of avian malaria and APV is higher in areas of agricultural development than in other locations because vector densities are higher in agricultural areas (Reiter \& LaPointe 2007). Similarly, in the Galapagos, the association of key APV vectors with land-use patterns suggests land-use type may affect pathogen transmission, as could other ecological factors associated with climate, elevation, and vegetation. Future studies comparing individual Galapagos Islands with varying levels of development could further elucidate the relation between environmental characteristics, land-use patterns, and immune function in wild bird populations. Understanding the underlying causes of disease variation among land-use types will be important for improving models of pathogen dynamics and developing recommendations for changes in agricultural policy and practices that could help improve population viability in the face of the APV threat.

\section{Acknowledgments}

We thank staff members of the Charles Darwin Research Station for logistic support; G. Jiménez-Uzcátegui for training in AP identification; P. Parker for permit assistance; R. Mills for field assistance; T. Hahn, J. Wingfield, and the Hahn-Wingfield-Ramenofsky lab groups for valuable discussions; and 3 anonymous reviewers whose comments greatly improved this paper. This work was funded by grants from the American Ornithologists' Union, Sigma Xi, University of California Davis Office of Graduate Studies and Hemispheric Institute on the Americas; the Max Planck Institute for Ornithology; and TAME 
(provided discount airfare). M.Z. was supported by a National Science Foundation Graduate Research Fellowship.

\section{Literature Cited}

Atkinson, C. T., J. K. Lease, R. J. Dusek, and M. D. Samuel. 2005. Prevalence of pox-like lesions and malaria in forest bird communities on leeward Mauna Loa Volcano, Hawaii. Condor 107:537-546.

Bataille, A., A. A. Cunningham, V. Cedeño, L. Patiño, A. Constantinou, L. D. Kramer, and S. J. Goodman. 2009. Natural colonization and adaptation of a mosquito species in Galápagos and its implications for disease threats to endemic wildlife. Proceedings of the National Academy of Sciences of the United States of America 106:1023010235.

Campbell, T. W. 1995. Avian hematology and cytology. Iowa State University Press, Ames.

Caroll, M. C., and A. P. Prodeus. 1998. Linkages of innate and adaptive immunity. Current Opinion in Immunology 10:36-40.

Casali, P., and E. W. Schettino. 1996. Structure and function of natural antibodies. Current Topics in Microbiology and Immunology 210:167-179.

Chasar, A., C. Loiseau, G. Valkiunas, T. Iezhova, T. B. Smith, and R. N. M. Sehgal. 2009. Prevalence and diversity patterns of avian blood parasites in degraded African rainforest habitats. Molecular Ecology 18:4121-4133.

Diamond, J. 1994. Ecological collapses of past civilizations. Proceedings of the American Philosophical Society 138:363-370.

Duffy, D. C., and S. Harcourt. 1981. An investigation of avian pox disease: its distribution and effects on Galapagos birds. Pages 108-111 in D. C. Duffy, D. J. Reynolds, and M. J. Campos, editors. Annual report of the Charles Darwin research station. Charles Darwin Foundation, Galapagos, Ecuador.

Fairbrother, A., J. Smits, and K. A. Grasman. 2004. Avian immunotoxicology. Journal of Toxicology and Environmental Health, Part B 7:105-137.

Fokidis, H. B., M. Orchinik, and P. Deviche. 2009. Corticosterone and corticosteroid binding globulin in birds: relation to urbanization in a desert city. General and Comparative Endocrinology 160:259-270.

Freeman, S., and W. M. Jackson. 1990. Univariate metrics are not adequate to measure avian body size. The Auk 107:69-74.

Fuller, R. A., P. H. Warren, P. R. Armsworth, O. Barbosa, and K. J. Gaston. 2008. Garden bird feeding predicts the structure of urban avian assemblages. Diversity and Distributions 14:131-137.

Gross, W. B., and H. S. Siegel. 1983. Evaluation of the heterophil/lymphocyte ratio as a measure of stress in chickens. Avian Diseases 27:972-979.

Hawley, D. M., K. Lindström, and M. Wikelski. 2006. Experimentally increased social competition compromises humoral immune responses in house finches. Hormones and Behavior 49:417-424.

Hirsch, R. L. 1982. The complement system: its importance in the host response to viral infection. Microbiology and Molecular Biology Reviews 46:71-85

Hosseini, P. R., A. A. Dhondt, and A. Dobson. 2004. Seasonality and wildlife disease: how seasonal birth, aggregation and variation in immunity affect the dynamics of Mycoplasma gallisepticum in house finches. Proceedings of the Royal Society of London. Series B: Biological Sciences 271:2569-2577.

Janeway, C. A., P. Travers, M. Walport, and M. Shlomchik. 2001. Immunobiology. Garland Science, New York.

Kidd, M. 2004. Nutritional modulation of immune function in broilers. Poultry Science 83:650-657.

Kleindorfer, S., and R. Y. Dudaniec. 2006. Increasing prevalence of avian poxvirus in Darwin's finches and its effect on male pairing success. Journal of Avian Biology 37:69-76.

Lindström, K., J. Foufopoulos, H. Pärn, and M. Wikelski. 2004. Immunological investments reflect parasite abundance in island populations of Darwin's finches. Proceedings of the Royal Society of London. Series B: Biological Sciences 271:1513-1519.

Matson, K. D. 2006. Are there differences in immune function between continental and insular birds? Proceedings of the Royal Society Biological Sciences Series B 273:2267-2274

Matson, K. D., R. E. Ricklefs, and K. C. Klasing. 2005. A hemolysishemagglutination assay for characterizing constitutive innate humoral immunity in wild and domestic birds. Developmental and Comparative Immunology 29:275-286.

Matson, K. D., B. I. Tieleman, and K. C. Klasing. 2006. Capture stress and the bactericidal competence of blood and plasma in five species of tropical birds. Physiological and Biochemical Zoology 79:556564 .

Meyers, L. A., B. Pourbohloul, M. E. J. Newman, D. M. Skowronski, and R. C. Brunham. 2004. Network theory and SARS: predicting outbreak diversity. Journal of Theoretical Biology 232:7181.

Millet, S., J. Bennett, K. A. Lee, M. Hau, and K. C. Klasing. 2007. Quantifying and comparing constitutive immunity across avian species. Developmental and Comparative Immunology 31:188201

Nunn, C. L., and E. W. Heymann. 2005. Malaria infection and host behavior: a comparative study of Neotropical primates. Behavioral Ecology and Sociobiology 59:30-37.

O'Connor, J. A., R. Y. Dudaniec, and S. Kleindorfer. 2010. Parasite infestation and predation in Darwin's small ground finch: contrasting two elevational habitats between islands. Journal of Tropical Ecology 26:285-292.

Parker, P. G., E. L. Buckles, H. Farrington, K. Petren, N. K. Whiteman, R. E. Ricklefs, J. L. Bollmer, and G. Jiménez-Uzcátegui. 2011. 110 years of avipoxvirus in the Galapagos Islands. Public Library of Science ONE 6: e15989.

Patz, J. A., T. K. Graczyk, N. Geller, and A. Y. Vittor. 2000. Effects of environmental change on emerging parasitic diseases. International Journal for Parasitology 30:1395-1405.

Quaye, I. K. 2008. Haptoglobin, inflammation and disease. Transactions of the Royal Society of Tropical Medicine and Hygiene 102:735742

Quinn, M. J., and M. A. Ottinger. 2006. Embryonic effects of androgen active endocrine disrupting chemicals on avian immune and reproductive systems. The Journal of Poultry Science 43:111.

Reiter, M. E., and D. A. LaPointe. 2007. Landscape factors influencing the spatial distribution and abundance of mosquito vector Culex quinquefasciatus (Diptera: Culicidae) in a mixed residential: agricultural community in Hawai'i. Journal of Medical Entomology 44:861-868.

Smits, J. E., J. L. Tella, M. Carrete, D. Serrano, and G. López. 2005. An epizootic of avian pox in endemic Short-toed Larks (Calandrella rufescens) and Berthelot's Pipits (Anthus bertbelotti) in the Canary Islands, Spain. Veterinary Pathology Online 42:59-65.

Suorsa, P., H. Helle, V. Koivunen, E. Huhta, A. Nikula, and H. Hakkarainen. 2004. Effects of forest patch size on physiological stress and immunocompetence in an area-sensitive passerine, the Eurasian treecreeper (Certbia familiaris): an experiment. Proceedings of the Royal Society of London. Series B: Biological Sciences 271:435-440.

Thomas, P. T., and R. V. House. 1989. Pesticide-induced modulation of the immune system. Pages 94-106 in Carcinogenicity and pesticides. American Chemical Society, Washington, DC.

van Riper C., III, and D. J. Forrester. 2007. Avian pox. Pages 131-176 in N. J. Thomas, D. B. Hunter, and C. T. Atkinson, editors. Infectious diseases of wild birds. Blackwell Publishing, Oxford, United Kingdom.

van Riper, C., III, S. G. van Riper, and W. R. Hansen. 2002. Epizootiology and effect of avian pox on Hawaiian forest birds. The Auk 119:929942 
Vargas, H. 1987. Frequency and effect of pox-like lesions in Galapagos Mockingbirds. Journal of Field Ornithology 58:101-102.

Whiteman, N. K., S. J. Goodman, B. J. Sinclair, T. I. M. Walsh, A. A. Cunningham, L. D. Kramer, and P. G. Parker. 2005. Establishment of the avian disease vector Culex quinquefasciatus Say, 1823 (Diptera: Culicidae) on the Galápagos Islands, Ecuador. Ibis 147:844-847.

Wicher, K. B., and E. Fries. 2006. Haptoglobin, a hemoglobin-binding plasma protein, is present in bony fish and mammals but not in frog and chicken. Proceedings of the National Academy of Sciences of the United States of America 103:4168-4173.
Wiedenfeld, D. A., and G. A. Jiménez-Uzcátegui. 2008. Critical problems for bird conservation in the Galápagos Islands. Cotinga 29:2227.

Wikelski, M., J. Foufopoulos, H. Vargas, and H. Snell. 2004. Galápagos birds and diseases: invasive pathogens as threats for island species. Ecology and Society 9: 5.

Zylberberg, M., K. A. Lee, K. C. Klasing, and M. Wikelski. 2012. Increasing avian pox prevalence varies by species, and with immune function, in Galápagos finches. Biological Conservation 153:7279

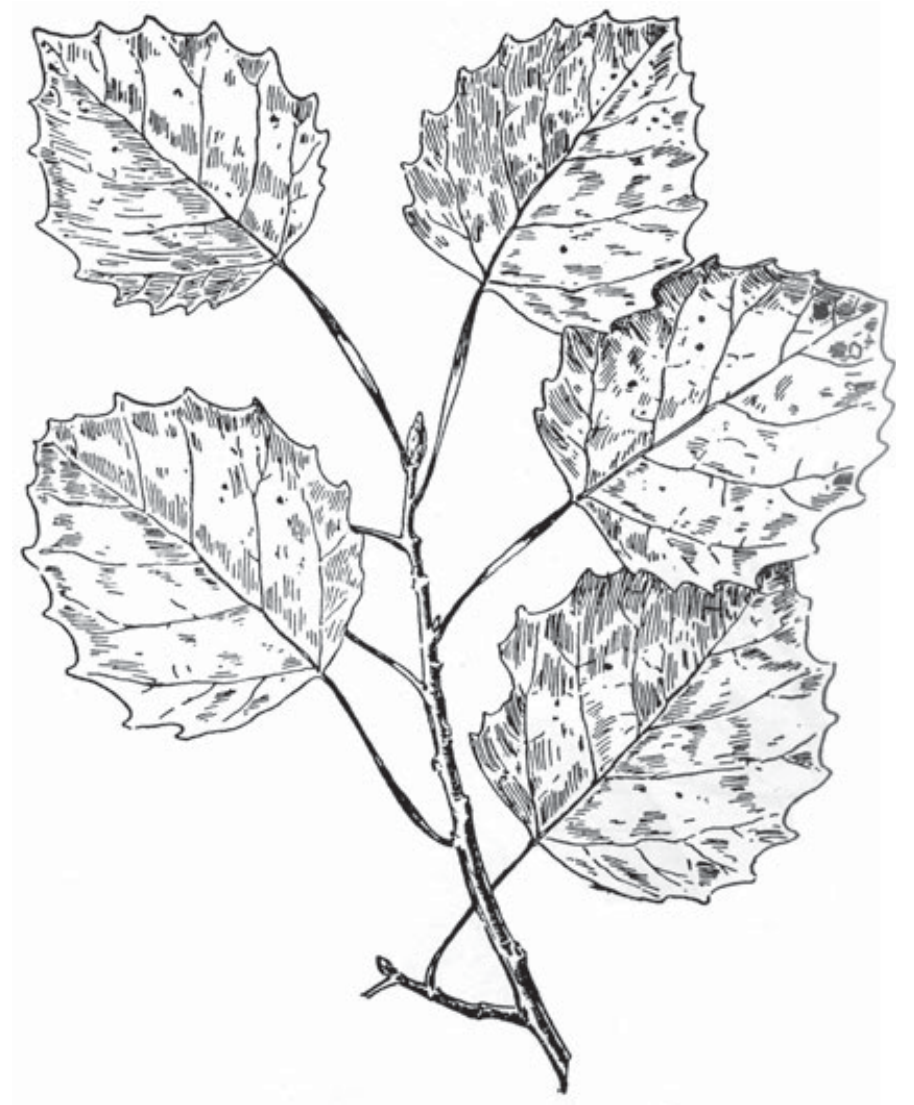

